\title{
Current status of glucosamine and chondroitin therapy in osteoarthritis
}

\author{
Errol Hutagalung
}

\begin{abstract}
Abstrak
Osteoarthritis (OA) merupakan arthritis yang paling banyak didapat. Perubahan radiologik dan atau patologik OA didapat pada mayoritas orang yang berusia lebih dari 65 tahun. Tatalaksana OA dibagi atas terapi bedah dan terapi non bedah. Terapi non bedah terdiri dari terapi farmakologik dan terapi non farmakologik seperti edukasi, latihan dan modifikasi gaya hidup. Bagi banyak penderita OA terapi farmakologik masih problematik, karena obat-obat yang digunakan dirasakan kurang efektif ataupun karena toksisitasnya, sehingga banyak penderita OA mencari terapi alternatif. Di kelompok terapi alternatif, maka glukosamin dan kondroitin merupakan zat yang paling sering dipakai. Telah banyak penelitian dilakukan untuk menilai efektifitas glukosamin dan kondroitin sebagai terapi terhadap OA. Hasil penelitian-penelitian tersebut ternyata masih kontroversial. Tinjauan pustaka ini akan mengupas status terkini dari glukosamin dan kondroitin pada pengobatan OA. (Med J Indones 2005; 14: 55-8)
\end{abstract}

\begin{abstract}
Osteoarthritis $(O A)$ is the most common form of arthritis. Radiographic and or pathologic changes of OA are present in most people older than 65 years old. The management of $\mathrm{OA}$ is divided into medical / non surgical and surgical treatment. The medical treatment consisted of pharmacologic and non pharmacologic treatment. The pharmacologic treatment of OA is still problematic for many patients, either due to a lack of efficacy or due to the toxicity of the drugs used in the treatment of OA, so that many OA patients seek for alternative medication. Glucosamine and chondroitin are the most commonly used alternative agents for the treatment in OA. Many studies had been conducted to evaluate the efficacy of glucosamine and chondroitin in the treatment of OA. So far the result is controversial. The purpose of this article is to highlight the current status of the use of glucosamine and chondroitin in OA treatment. (Med J Indones 2005; 14: 55-8)
\end{abstract}

Keywords : Osteoarthritis, Glucosamine, Chondroitin

Osteoarthritis (OA) is the most common form of arthritis. ${ }^{1-2}$ In U.S.A. it is estimated that $12.1 \%$ of Americans age 25 years and older (nearly 21 millions persons in 1990) have clinical signs and symptoms of OA. ${ }^{1}$ Radiographic and or pathologic changes of OA are present in most people older than 65 years. ${ }^{3}$ Hinton et $\mathrm{al}^{4}$, in 2002, estimated that 40 million Americans of all ages are affected by OA and that 70 to $90 \%$ of Americans older than 75 years have at least one involved joint. The incidence of OA is approximately twice as high in women as in men. ${ }^{5}$

The estimated cost of OA to the US economy in 1994 were estimated to be 15.5 billions dollars. ${ }^{1}$

Division of Orthopaedic and Traumatology, Faculty of Medicine University of Indonesia/Dr. Cipto Mangunkusumo Hospital, Jakarta, Indonesia
The goals of OA therapy as outlined in 1995 Americans College of Rheumatology (ACR) guidelines are to decrease pain and to maintain or improve joint function, minimize disability, and educate patients and their families about the disease and its treatment. ${ }^{3}$

The management of OA is broadly divided into medical/non surgical and surgical treatment. Medical treatment consisted of pharmacologic and non pharmacologic treatment such as education, exercises, modification of lifestyle.

The pharmacologic therapy of OA is still problematic for many patients, either due to a lack of efficacy, or due to the toxicity associated with the currently available treatment options, so that many patients who suffered from this chronic disease seek for alternative medication. ${ }^{1}$

$\mathrm{OA}$ is the leading medical condition for which persons use alternative therapies, because conventional 
medication has side effects or incomplete relief of symptoms. Alternative therapies used for the treatment of OA include herbs, supplements and non drug modalities such as exercise, physical therapy, acupuncture and electromagnets. Glucosamine and chondroitin are two of molecular building blocks found in articular cartilage and are the most commonly used alternative supplements for the treatment in OA. ${ }^{6}$

In recent years, numerous studies have investigated potential chondroprotective agents, substances that are capable of increasing the anabolic activity of chondrocytes while simultaneously suppressing the degradative effects of cytokine mediators on cartilage. It has been suggested that such agents may repair articular cartilage, or at least decelerate its progressive degradation. Among those substances that may possess chondroprotective properties are glucosamine sulfate, chondroitin sulfate, hyaluronic acid, piroxicam, tetracyclines, corticosteroids, and heparinoids. ${ }^{5}$ Publicity relating to the clinical experience with the first two of these agents (e.i. glucosamine and chondroitin sulfate), has created an air of controversy surrounding their use as alternative agents in the treatment of osteoarthritis.

The purpose of this article is to highlight the current status of the use of Glucosamine and Chondroitin in the treatment of OA.

\section{Cartilage Structure and Function}

Cartilage is composed of water, collagen and proteoglycans. $^{2}$ The interaction of these matrix components imparts the characteristic biomechanical properties of flexibility and resistance to compression of cartilage.

Proteoglycans - large macromolecules consisting of multiple chains of glycosaminoglycans and oligosaccharides attached to a central protein core - provide a framework for collagen and also bind water and cations, forming a viscous, elastic layer that lubricates and protects cartilage.

The collagen component of the cartilage matrix is relatively inert, but the other constituent, such as proteoglycans, undergo a distinct turnover process during which the catabolism and removal of molecules from the extracellular matrix is in balance with the synthesis and deposition of new molecules. In OA the production of proteoglycans does not keep in pace with its loss, there is an imbalance between synthesis and degradation, resulting in a net loss of cartilage matrix. ${ }^{5}$

Glucosamine is an aminosaccharide that takes part in the synthesis of glycosaminoglycans and proteoglycans by chondrocytes. Glucosamine also serves as a substrate for the biosynthesis of chondroitin sulfate, hyaluronic acid, and other macromolecules located in the cartilage matrix.

Chondroitin sulfate is a glycosaminoglycans composed of a long, unbranched polysaccharide chain of alternating residues of sulfated or unsulfated residues of glucoronic acid and $\mathrm{N}$-acetylgalactosamine. ${ }^{5}$

These proteoglycans function to draw water into the tissue, creating a high osmotic pressure that causes swelling and expansion of the matrix. The load bearing properties of cartilage are attributable to the compressive resilience and affinity for water of these high molecular weight compounds that fill the interfibrillar collagen matrix. ${ }^{5}$

\section{Pharmacokinetics}

Glucosamine has been studied as a therapeutic agent for OA for almost two decades, but only recently has it become a popular remedy for treating OA. ${ }^{7}$ The lack of interest in glucosamine by researchers and pharmaceutical companies in general has been attributed by some to the fact that glucosamine is a natural product that cannot be patented. ${ }^{8}$ A search of the Worldwide Web using the AltraVista engine searching for the term glucosamine revealed more than 34.000 web pages. Most of the web sites contain anecdotal reports of the benefit of glucosamine and advertising by numerous manufacturers of glucosaminecontaining products. ${ }^{7}$

James Lind, 250 years ago, stated that eating oranges and lemons can cure scurvy. The scientific rationale of his statement was not clear, but the outcome was very clear, not until in the early 1930 when Szent Gyorgyi isolated vitamin $\mathrm{C}$ from oranges and lemons, and showed that vitamin $\mathrm{C}$ could prevent and cure scurvy. As a result of Lind's work and that of others who demonstrated that dietary deficiencies cause a variety of diseases, the concept of preventing and treating disease with the use of dietary supplements has become generally accepted. A particularly interesting manifestation of this concept is the belief that eating 
cartilage or its component molecules rebuilds damaged joints and prevents arthritis. ${ }^{9}$

Despite its extensive use, little is known about the bioavailability or pharmacokinetics of glucosamine sulfate. After oral, intramuscular, or intravenous administration, it is broken down into D-glucosamine and sulfate. Pharmacokinetics data are available only from a small study that examined oral, intramuscular, and intravenous glucosamine sulfate administration. ${ }^{7}$

Jian Hua et al, ${ }^{10}$ stated that glucosamine suppresses the neutrophil functions, thereby possibly exhibiting antiinflammatory actions in arthritis.

\section{Clinical Trials $^{5-12}$}

The majority of clinicals trials performed to evaluate the efficacy of glucosamine and chondroitin sulfate in the treatment of OA have demonstrated a decrease in joint pain, tenderness, and swelling and an increase in mobility. These studies were randomized, double blind, placebo controlled, and compared to NSAID (ibuprofen, diclofenac), done in multi center with meta analyses. The duration of these trials range from 4 to 16 weeks. These studies used the scoring system of Lequesne Index, Global Pain Score and Western Ontario \& Mc Master University (WOMAC) OA Index. The dosage used in the studies :1500 mg Glucosamine $\mathrm{Hcl} /$ day and $1200 \mathrm{mg}$ Chondroitin SO4/day.

These studies concluded that compared to placebo both agents had a significant outcome in reducing the complaints of OA patients. Compared to NSAID, it had a similar effect or even better, but NSAID had faster response (in week 1). Adverse effects in the NSAID group was significantly higher, that is $35 \%$ compared to glucosamine and chondroitin group: $6 \%$. Due to this adverse effect there were $10 \%$ dropout in NSAID group, while in the glucosamine and chondroitin group there was no dropout. In the NSAID group symptoms emerge soon after discontinuation, while in the glucosamine and chondroitin group although had a slower initial response, but exhibit 3 months favorable result after stopping therapy.

Summing up these studies concluded that glucosamine and chondroitin sulfate had beneficial effect in treating OA patients.

The proposed mechanisms of action are : increase of proteoglycans synthesis while in the same time there is decrease of proteoglycans degradation, and there is also decrease of inflammation process due to suppression of neutrophil function.

Nevertheless, these studies leave important questions unanswered. Does ingestion of glucosamine aand chondroitin sulfate affects synovial joints and relieve pain by stimulating proteoglycan synthesis, by suppressing inflammation, or by mechanisms that have not yet been considered ?. Do these substances have any long-term adverse effect? What are the optimal doses? ${ }^{9}$

Glucosamine and chondroitin sulfate are classified as dietary supplements. In USA, the law allows all dietary supplements to be sold to the public without any testing for efficacy or safety and without any manufacturing standards, and these substances are not under the control of the FDA. In fact, manufacturers are allowed to make all sorts of claims for their glucosamine/chondroitin sulfate products just short of saying that their product cures arthritis.

Recently several trials that give negative results in the use of glucosamine/chondroitin for treatment OA patients have been published. It is not easy to reconcile the results of these negative trials with the favorable results from the earlier trials. However, these negative trials had no affiliation with a manufacturer of glucosamine/chondroitin products. ${ }^{1}$

The meta analyses by McAlindon et al, ${ }^{12}$ provided a useful critical analysis of the methodologic concerns associated with the published glucosamine/chondroitin trials. They showed methodologic flaws in many of the published trials; these flaws have been associated with exaggerated estimates of treatment of treatment benefit. Methodologic flaws identified in the trials included inadequate allocation concealment, absence of intention to treat analyses, and publication bias. Although it seems unlikely, it is still possible that these biases could negate significantly the supposed efficacy of glucosamine/chondroitin. They also showed that there is inconsistencies in study design, and the size of the sample is small.

Unfortunately, patients with a chronic disease such as osteoarthritis, are willing to try alternative therapies in the hope of a cure and are lured to these products by frequent advertisement on the television and in printed media.

As of 1999, the National Institute of Health of USA started a large, placebo controlled, long term study- 
GAIT (Glucosamine/Chandroitin Arthritis Intervention Trial) study, that as of 2003 has not yet ended. GAIT study compared glucosamine/chondroitin with celecoxib and placebo in the treatment of symptomatic OA of the knee. ${ }^{1,6}$

To summarize this review, short term studies showed that glucosamine / chondroitin sulfate is beneficial in the treatment of OA. However, these studies showed deficiency in study design and leaves some important questions unanswered, and also there is a strong sponsorship. Recently negative results about the efficacy of glucosamine/chondroitin in the treatment of OA has been published, so it creates an air of controversy. The result of GAIT study are eagerly awaited, hopefully the result of the study will settle the controversy about the effectiveness of glucosamine / chondroitin in the treatment of symptomatic OA.

\section{REFERENCES}

1. Towheed TE. Current status of glucosamine therapy in osteoarthritis. Arthritis Rheum 2003; 49:601-4.

2. American College of Rheumatology Subcommittee on Osteoarthritis Guidelines. Recommendations for the medical management of osteoarthritis of the hip and the knee: 2000 update. Arthritis Rheum 2000;43:1905-15.

3. Manek MJ. Medical management of osteoarthritis. Mayo Clin Proc 2001;76:533-9.
4. Hinton R, Moody RL, Davis AW, Thomas SF. Osteoarthritis: Diagnosis and Therapeutic considerations. Am Fam Physician 2002;65:841-8.

5. Brief AA, Maurer SG, Di Cesare PE. Use of glucosamine and chondroitin sulfate in the management of osteoarthritis. J Am Acad Orthop Surg 2001;9:71-8.

6. Morelli V, Naquin C, Weaver V. Alternative therapies for traditional disease states: osteoarthritis. Am Fam Physician 2003;67:339-44.

7. Delafuente JC. Glucosamine in the treatment of osteoarthritis. Rheum Dis Clin North Am 2000;26:1-11.

8. Thie NMR, Prasad NG, Major PW. Evaluation of glucosamine sulfate compared to ibuprofen for the treatment of temporomandibular joint osteoarthritis: A randomized double blind controlled 3 month clinical trial. J Rheumatol 2001;28:1347-55.

9. Buckwalter JA, Callaghan JJ, Rosier RN. From oranges and lemons to glucosamine and chondroitin sulfate: clinical observations stimulate basic research. J Bone Joint Surg 2001;83 A:1266-8.

10. Hua J, Sakamoto K, Nagaoka A. Inhibitory action of glucoamine, a therapeutic agent for osteoarthritis, on the functions of neutrophils. J Leukoc Biol 2002;71:632-40.

11. Lozada CJ, Altman RD. New and investigational therapies for osteoarthritis. In:Moskowitz RW, Howell DS, Altman RD, Buckwalter JA, Goldberg VM, editors. Osteoarthritis. $3^{\text {rd }}$ ed. Philadelphia: WB. Saunders Company;2001.p.44758.

12. McAlindon TE, LaValley MP, Gulin JP, Felson DT. Glucosamine and chondroitin for treatment of osteoarthritis : a systematic quality assessment and metaanalysis. JAMA 2000;283:1469-75. 